contributions to the subject of foliar periodicity in the local flora, and made an intensive study of the genus Diospyros in Ceylon.

From 1907 until 1917 Wright was editor of the India Rubber Journal, London, and was associated with various public companies and trusts dealing with tropical agriculture. During 1931-38 he was chairman of the finance committee of the governing body and treasurer of the Imperial College of Science and Technology, South Kensington. He also held other offices in connexion with the Imperial College at different times. He was a fellow of the Linnean Society, and was knighted in 1930.

\section{Mr. E. L. Rhead}

By the death on October 19 of Mr. Ezra Lobb Rhead, one of the last remaining representatives of the older school of metallurgists passed away. For forty-five years he lectured on metallurgy and assaying in the Manchester College of Technology, being a representative of the University's Faculty of Technology from its inception in 1904.

He was a teacher with a special gift for, and love of, his profession, who inspired in his pupils a real affection. Of the thousands of students who passed through his department, many have risen to positions of eminence. From all parts of the world his old students corresponded with him, and this continued friendship was a source of great satisfaction to him, especially, perhaps, in the years after his resignation from his lectureship. His interest in the welfare of the teaching profession was particularly marked in his support of the Association of Teachers in Technical Institutions, of which he was the president in three successive years.

Mr. Rhead contributed papers on a wide variety of subjects to the metallurgical societies and institutions in which he was interested. He was the author of several text-books on metallurgy, foundry practice and assaying, and he enjoyed the confidence of manufacturers, to whom his scientific knowledge and practical experience were always available.

Perhaps the outstanding charaeteristic of Rhead was the affection which he inspired in all those who really knew him, and the great kindness of heart which he invariably showed to those who asked for his help and advice.

\section{F. C. Thompson.}

\section{Mr. W. G. Spencer, O.B.E.}

Mr. WaLter George Spencer, the well-known surgeon and medical historian, died on October 31 after a short illness in Westminster Hospital at the age of eighty-three. He was educated at Weymouth College and St. Bartholomew's Hospital, and qualified in 1885. Throughout his career he was closely connected with Westminster Hospital, of which he was vice-president, as well as lecturer and successively assistant surgeon, surgeon, and consulting surgeon.
He was also a prominent figure at the Royal College of Surgeons, where he was a vice-president, a member of the Court of Examiners, and gave the Arris and Gale, Erasmus Wilson, Bradshaw and Vicary Lectures. During the War of 1914-18 he served as major in the R.A.M.C., and was attached to the Fourth London General Hospital. Besides his clinical activities he took a keen interest in experiments on animals, and contributed two important papers to the Philosophical Transactions, the first in 1891 in conjunction with Victor Horsley on "The Changes Produced in the Circulation and Respiration by Increase of the Intracranial Pressure or Tension", and the second in 1894 on "The Effect Produced upon Respiration by Faradic Excitation of the Cerebrum in the Monkey, Dog, Cat and Rabbit". He also delivered a Hunterian Lecture at the Royal College of Surgeons in 1920 on "Animal Experiments and Surgery".

Mr. Spencer did valuable service at the Royal Society of Medicine, where he was president of the Sections of Surgery in 1920-21 and the History of Medicine in 1926-28, as well as honorary librarian in 1916-28. He was also honorary librarian for many years at the British Medical Association, and a member of the Committee of the London Library, at which he was a frequent visitor until shortly before his death. His chief contributions to medical history were his "Westminster Hospital : An Outline of its History" (1924), his collaboration with Sir D'Arcy Power and Prof. G. E. Gask in the revision of Plarr's "Lives of the Fellows of the Royal College of : Surgeons of England" (1930), and a translation of Celsus in the Loeb Classical Library (1935-38). Healsotook an active part in the organization of the second International Congress of the History of Medicine held in London in 1922, when he acted as honorary treasurer and co-editor with the present writer of its proceedings.

\section{J. D. Rolleston.}

WE regret to announce the following deaths :

Mr. H. H. Baker, president of the New South Wales Branch of the British Astronomical Association, on August 13, aged seventy-two.

Dr. F. W. Edwards, F.R.S., deputy keeper of entomology in the British Museum (Natural History), on November 15, aged fifty-one.

Prof. E. W. MacBride, F.R.S., emeritus professor of zoology in the University of London, on November 17, aged seventy-three.

Dr. S. P. McCallum, University demonstrator in physics, Oxford, on November 16, aged fortyfive.

M. Charles Nordman, director of the Paris Observatory since 1920, on November 15, aged fifty-nine.

Prof. Hans Rosenberg, an authority on astronomical photometry, formerly director of the Kiel Observatory and lately director of the Observatory at Istanbul, on July 26, aged sixty-one.

Prof. George Rutledge, professor of mathematics in the Massachusetts Institute of Technology, on September 21, aged fifty-eight years. 